\title{
Dental treatment of post-myocardial infarction patients: A review of the literature
}

\section{Leczenie stomatologiczne pacjentów po przebytym zawale mięśnia sercowego - przegląd piśmiennictwa}

\author{
Renata Samulak-Zielińskaa ${ }^{1, A, B, D, F}$, Elżbieta Dembowska ${ }^{1, D-F}$, Piotr Lizakowski ${ }^{2, B, D-F}$ \\ ${ }^{1}$ Departament of Periodontology, Pomeranian Medical University in Szczecin, Poland \\ ${ }^{2}$ Specialist Medical Practice in Szczecin, Poland \\ A - research concept and design; $\mathrm{B}$ - collection and/or assembly of data; $\mathrm{C}$ - data analysis and interpretation; \\ $D$ - writing the article; $E$ - critical revision of the article; $F$ - final approval of the article
}

Address for correspondence

Renata Samulak-Zielińska

E-mail: renata.samulak.zielinska@gmail.com

Funding sources

None declared

Conflict of interest

None declared

Received on January 2, 2019

Reviewed on February 20, 2019

Accepted on May 8, 2019

Published online on September 30, 2019

Cite as

Samulak-Zielińska R, Dembowska E, Lizakowski P. Dental

treatment of post-myocardial infarction patients: A review

of the literature. Dent Med Probl. 2019;56(3):291-298.

doi:10.17219/dmp/109232

DOI

$10.17219 / \mathrm{dmp} / 109232$

Copyright

๑ 2019 by Wroclaw Medical University

This is an article distributed under the terms of the

Creative Commons Attribution 3.0 Unported License (CC BY 3.0)

(https://creativecommons.org/licenses/by/3.0/)

\begin{abstract}
Patients who have suffered a heart attack often require dental treatment. The inflammation of the oral cavity not only reduces the quality of life, but also negatively affects the course of ischemic heart disease. Dental treatment in patients with a history of myocardial infarction seems complicated, since these patients require special consideration with regard to the timing and form of dental treatment as well as to the precautions required. Patients at risk of cardiac complications that are greater than the benefits of dental treatment should be identified and only the most urgent conditions should be treated. The aim of this study was to present the latest guidelines for dental treatment in patients who have suffered myocardial infarction. We reviewed the available literature explaining when dental treatment can be undertaken, whether antibiotic prophylaxis is required, whether the patient can be anesthetized locally, and how to provide the maximum safety during the visit. The principles of the surgical treatment of patients receiving drugs that affect hemostasis were also reviewed.
\end{abstract}

Key words: dental care, oral anticoagulants, antibiotic prophylaxis, myocardial infarction

Słowa kluczowe: opieka stomatologiczna, doustne antykoagulanty, profilaktyka antybiotykowa, zawał mięśnia sercowego 


\section{Introduction}

The number of patients with general diseases requiring dental treatment is on the increase. According to the estimates presented in Bhateja's report, out of 36,729 patients of Dental College and Hospital in Mathura, India, 58\% had a history of cardiovascular disease. ${ }^{1}$ Such patients require an individualized treatment plan and the continuous monitoring of oral health. The current state of knowledge indicates that inflammation in the oral cavity, particularly periodontitis, affects the general state of health, including the development and course of atherosclerosis. Cardiovascular disease has an inflammatory origin. Firstly, there is an increase in the level of pro-inflammatory mediators in response to the presence of Gram-negative lipopolysaccharides (LPSs), C-reactive protein (CRP), interleukin $1 \beta$ and interleukin 6 (IL-1 $\beta$ and IL-6), tumor necrosis factor alpha (TNF- $\alpha$ ), fibrinogen, and matrix metalloproteinase 9 (MMP-9). These substances contribute to the destabilization of the atherosclerotic plaque. ${ }^{2}$ Secondly, there is a cross-reaction of the patient's antibodies with heat shock protein (HSP) present in the damaged vascular endothelium and atherosclerotic plaques. This leads to the continuation of the inflammatory process, and thus to the progression of the disease. Cross-reactivity is triggered by the presence of oral bacteria Porphyromonas gingivalis and Tannerella forsythia, whose HSP is in 60\% homologous to HSP found in mammals. ${ }^{3}$ Thirdly, direct bacterial mechanisms (e.g., bacterial enzyme activity) contribute to the progression of cardiovascular disease. Bacterial DNA of Tanerella forsythia, Porphyromonas gingivalis, Aggregatibacter actinomycetemcomitans, and Prevotella intermedia has been found in the atherosclerotic plaque. ${ }^{4}$ Finally, the concept of 'vascular endothelial activation' can explain the mechanism underlying inflammatory-induced atherosclerotic plaque formation. The LPS binding, bacterial outer membrane vesicles, fimbriae, and other bacterial antigenic structures have an impact on the local and systemic host response. This leads to the upregulation of endothelial cell receptors followed by monocyte adhesion to the vascular wall. Monocytes migrate into the subendothelial space, absorb low-density lipoprotein cholesterol (LDL-C) and become foam cells. After their apoptosis, lipids are accumulated in the vessel wall, covered by matrix and accompanied by smooth muscle cell proliferation, which is induced by invasive periodontal pathogens. The enzymatic degradation of the extracellular matrix results in plaque rupture, the exposure of prothrombotic components and subsequent thrombus formation, which ultimately leads to blood vessel occlusion. ${ }^{4}$ This results in a need for treatment of oral cavity diseases as well as in intensive efforts toward periodontal disease prevention in patients with cardiovascular diseases. ${ }^{5}$

The need for periodontal treatment is significant among Polish patients after myocardial infarction. With regard to the Community Periodontal Index of Treatment
Needs (CPITN), 38.6\% of them have a score of 3 and $46 \%$ a score of 4 , meaning they are in urgent need of periodontal treatment. ${ }^{6}$ Questions concerning the safety of dental treatment of patients after myocardial infarction need to be addressed.

\section{Material and methods}

To identify key words, a Population, Intervention, Comparison and Outcome (PICO) question was formulated as: What are the safety rules for dental care of patients following myocardial infarction? A comprehensive search of the MEDLINE (PubMed), Scopus and Google Scholar electronic databases was undertaken in January 2019 to find relevant articles, using the following search terms: [dental care OR dental anesthesia OR tooth extraction] AND [myocardial infarction OR ischemic heart disease]. The timeframe was 2000-2019. Additionally, a manual search of the bibliographies of fulltext articles was also conducted. The guidelines of the American Heart Association (AHA), American College of Cardiology (ACC), European Society of Cardiology (ESC), and Polish Society of Cardiology were also reviewed. We considered reviews, systematic reviews, guidelines and statements of dental and cardiological associations, randomized controlled trials (RCTs) as well as cohort, case and cross-sectional studies. Papers with abstracts written in English or Polish were included. Letters, book chapters, case reports, and studies without an abstract or with no full text available were not included. Only publications addressing the protocol for the treatment of post-myocardial infarction patients were analyzed. Articles dealing with the influence of oral inflammation on cardiovascular disease or the effects of dental treatment on general health were excluded.

The limitations of this review include the open PICO question, the broad spectrum of relevant issues requiring urgent explanation, and the restriction to cardiological society guidelines and reviews rather than RCTs. Taking all this into account, only some of the Preferred Reporting Items for Systematic Reviews and Meta-Analyses (PRISMA) rules could be fulfilled. The study selection was conducted independently by 2 reviewers (PL and RSZ), with any disagreements resolved by the $3^{\text {rd }}$ reviewer (ED). A total of 37 articles were included in the review. No meta-analyses or systematic reviews were found.

Our findings were compatible with those presented by Napeñas et al. at a panel of experts during World Workshop on Oral Medicine VI. 7 They stated that "with a lack of consensus statements, guidelines, or systematic reviews focused on these specific issues related to dental treatment for patients with cardiovascular diseases, the vast majority of current recommendations are not linked to levels of evidence and are presumably derived from expert opinion"? 


\section{Appropriate time to start dental treatment in post-myocardial infarction patients}

Dental procedures are classified as minor surgical procedures of a low cardiovascular risk. The risk of death or myocardial infarction within 30 days of a dental procedure is less than $1 \%$. However, a patient after a heart attack is at high risk of recurrence of cardiovascular events. Only considering patients with acute ST-elevation myocardial infarction (STEMI), the risk of in-hospital death ranges from $4 \%$ to $14 \%$ and the annual mortality after a surgical intervention is $10 \% .^{8}$ Over $70 \%$ of relapses occur in the $1^{\text {st }}$ month after the initial incident. The risk of recurrence depends on the severity of the disease, type of disease, treatment applied, and possible complications of the infarction. ${ }^{5}$

The most burdened group of patients are those treated conservatively - currently only a small number, due to the pressure of cardiac society guidelines pertaining to early invasive treatment. In these cases, the natural course of the disease lasts for more than 6 weeks. ${ }^{9}$ This is the period needed for a post-infarction scar to form, to create collateral circulation and to restore the contractility of the damaged (but not necrotic) areas of the myocardium. To avoid late infarction complications, all procedures excluding emergency treatment should be avoided in this period. This also applies to dental surgery. Former AHA guidelines extended this period to 6 months, during which avoiding dental surgery was recommended, as the risk of complications was considered the highest in this period. ${ }^{10}$

Due to advances in cardiac management in the last 2 decades, these limitations are no longer recommended. Firstly, there is widespread access to the invasive methods of treatment of infarctions, allowing the immediate reperfusion of tissues, thus avoiding early and late complications. In addition, on the $2^{\text {nd }}$ day after myocardial infarction patients are subjected to early cardiac rehabilitation; this is continued after discharge in rehabilitation centers, where patients undergo fitness tests in the $1^{\text {st }}$ month of convalescence. When the patient's test tolerance is found to be good, the risk of recurrence is considered low, and if the attending physician does not find otherwise, there are no contraindications to dental treatment. ${ }^{5} \mathrm{~Pa}$ tients who had myocardial infarction in the past and are in a stable period of coronary heart disease do not need stress tests and can be assessed on the basis of an interview. In terms of metabolic equivalents of task (METs), efficiency at 4 METs is sufficient to qualify the patient for dental procedures.

Patients at risk of cardiac complications exceeding the benefits of dental treatment should be identified and only the most urgent conditions should be treated. However, pain and inflammation, which may be a consequence of avoiding dental treatment as a precaution against cardiac complications, are a source of endogenous catechol- amines that burden the already damaged heart muscle, which means caution might not always be the safest solution. The priority is to cure inflammation in the oral cavity, as it can cause pain similar to angina pectoris, with the same characteristic pain radiation. In addition, painful inflammation hinders food intake and interrupts sleep, resulting in a significant reduction in the quality of life. ${ }^{11}$ Endodontic treatment, conservative treatment, non-surgical periodontal treatment, or prophylactic treatment are considered procedures entailing a low risk of complications. In addition, the risk decreases in stable periods of coronary heart disease or after heart failure, when the symptoms have a constant intensity, are predictable and occur only after intense physical activity. A good determinant of the patient's condition is a lack of chest pain for 2 weeks and satisfactory test results. ${ }^{12}$ Most authors recommend a cautious 4-6-week period after myocardial infarction to stabilize the disease. ${ }^{13}$ During this period, the most indispensable procedures, such as extractions, the drainage of abscesses or pulpotomies can be performed in a hospital setting. After this period, unless the cardiologist recommends otherwise, complex dental treatment can be carried out. ${ }^{13}$

\section{Antibiotic prophylaxis in post-myocardial infarction patients}

Another issue is antibiotic prophylaxis prior to treatment, associated with the risk of bacteremia in patients who have suffered myocardial infarction. Patients with angina pectoris, cardiovascular events or coronary artery bypass surgery (bypass grafts) are classified as patients at low risk of infective endocarditis, and therefore antibiotic prophylaxis is not indicated. ${ }^{14}$ The same applies to stentinjected patients. Guidelines set by the Polish Dental Association and the National Antibiotic Protection Program in 2019 continue to support the 2015 guidelines of ESC on the prevention and treatment of infective endocarditis (Table 1). They recommend the use of antibiotics in a number of situations, including the presence of an artificial prosthetic valve, the presence of artificial material used to repair the valve (e.g., a mitral ring) and cyanotic congenital heart disease. In the cases of congenital heart defects repaired with artificial material, prophylaxis is recommended for 6 months after surgery, or permanently if the defect has not been completely corrected and there is intracardiac leakage. The guidelines do not include a history of myocardial infarction or bypass surgery as posing an increased risk of infection. They limit high-risk dental procedures to those in which the continuity of the mucous membranes is disrupted and the risk of injury to the gingival or periapical area is present. Such procedures require antibiotic prophylaxis only in selected cases mentioned above. ${ }^{15,16}$ However, some authors recommend antibiotics in the case of invasive procedures up to 30 days after the cardiological intervention. ${ }^{17}$ 
Table 1. Comparison of guidelines for the antibiotic prophylaxis of endocarditis

\begin{tabular}{|c|c|c|}
\hline $\begin{array}{c}\text { AHA } 2007 \\
\text { American Heart Association }{ }^{20}\end{array}$ & $\begin{array}{l}\text { ESC } 2015 \\
\text { European Society of Cardiology }{ }^{15}\end{array}$ & $\begin{array}{r}\text { Polish Denta } \\
\text { and National Antibiot } \\
201\end{array}$ \\
\hline $\begin{array}{l}\text { - patients with a prosthetic heart valve or who have had } \\
\text { - } \text { a heart valve repaired with prosthetic material } \\
\text { - patients with a history of endocarditis } \\
\text { valve function } \\
\text { - patients with certain congenital heart defects, including: } \\
\text { - cyanotic congenital heart disease (birth defects, } \\
\text { with oxygen levels lower than normal) that has not } \\
\text { been fully repaired, including children who have had } \\
\text { surgical shunts and conduits } \\
\text { - a congenital heart defect that has been completely } \\
\text { repaired with prosthetic material or a device, for the } \\
\text { first } 6 \text { months after the repair procedure } \\
\text { - repaired congenital heart disease with residual } \\
\text { defects, such as persisting leaks or abnormal flow at or } \\
\text { adjacent to a prosthetic patch or prosthetic device }\end{array}$ & $\begin{array}{l}\text { - patients with any prosthetic valve, } \\
\text { including a transcatheter valve, or those } \\
\text { in whom any prosthetic material was } \\
\text { used for cardiac valve repair } \\
\text { - patients with a previous episode } \\
\text { of infective endocarditis } \\
\text { - patients with congenital heart defects: } \\
\text { - any type of cyanotic congenital heart } \\
\text { defects } \\
\text { - any type of congenital heart defects } \\
\text { repaired with prosthetic material, } \\
\text { whether placed surgically or by } \\
\text { percutaneous techniques } \\
\text { - up to } 6 \text { months after the procedure } \\
\text { - lifelong if a residual shunt or valvular } \\
\text { regurgitation remains }\end{array}$ & $\begin{array}{l}\text { patients with an artificial heart valve, including } \\
\text { those implanted percutaneously, or patients } \\
\text { who have been treated with artificial material } \\
\text { for valve repair } \\
\text { patients after an episode of infective } \\
\text { endocarditis } \\
\text { patients with congenital heart disease, } \\
\text { including: } \\
\text { - patients with a congenital cyanotic heart } \\
\text { defect } \\
\text { - patients after the repair of a congenital } \\
\text { malformation of the heart with artificial } \\
\text { material, both during surgery and using } \\
\text { transcutaneous techniques for up to } 6 \\
\text { months after surgery, or lifelong if residual } \\
\text { leakage or valve regurgitation remains }\end{array}$ \\
\hline
\end{tabular}

In each case, the benefits and risks of possible antibiotic usage should be balanced. It should be noted that in postmyocardial infarction patients there may be indications for antibiotic prophylaxis resulting from other concomitant diseases. ${ }^{18}$ The most important factors in the prevention of infective endocarditis are good oral hygiene and oral inflammation prophylaxis. ${ }^{19,20}$

\section{Rules for safe dental treatment}

The basics of safe dental treatment of patients with cardiovascular diseases comprise a detailed medical history, including complaints, allergies, medications, and specialist recommendations. It is important to monitor the patient's condition and to interrupt the procedures when the patient becomes restless or cardiac problems arise. An angina attack can occur in the dental chair due to stress, pain and anxiety triggers. ${ }^{3}$ Pain can be felt in the jaw, from where it can radiate to the neck and throat, so in some cases, the patient and the dentist may interpret it as toothache. If the patient experiences retrosternal pain, the procedure should be interrupted, and sublingual nitroglycerin $(0.4-0.8 \mathrm{mg})$ and oxygen $(3 \mathrm{~L} / \mathrm{min})$ should be administered. If the pain subsides within $5 \mathrm{~min}$, the appointment can be continued or postponed to the next day. If the pain persists after $5 \mathrm{~min}$, nitrates should be given again. If there is no improvement after 15 min since the first symptoms occurred, a re-infarction should be suspected, and in this situation the patient should be transferred as soon as possible to an emergency department. ${ }^{5}$

Psychological and physiological stress during dental appointments has the potential to significantly alter hemodynamic stability. Therefore, a stress-reduction protocol is suggested for post-myocardial infarction patients, including profound local anesthesia, preoperative or intraoperative sedation and excellent post-operative analgesia. ${ }^{21}$ The dental visit should be short - up to $30 \mathrm{~min}$ - and in the middle of the day. Morning hours, with the highest incidence of myocardial infarction, and late afternoon hours, when fatigue and stress levels are high, should be avoided.

During dental procedures, a supine position should be avoided, as it leads to the return of blood from peripheral areas to the central circulation system and may overload pulmonary circulation. In cases of systolic heart failure following myocardial infarction, this overload may result in the aggravation of heart failure, including pulmonary edema after re-verticalization, and further contribute to orthostatic syncope. ${ }^{8}$ The patient should continue to take the medication before the appointment as directed by the attending physician. If the patient's regular therapy includes nitrates, the patient should bring them. In cases of anxiety disorders and stress, the administration of 5-10 $\mathrm{mg}$ of diazepam is recommended the night prior to the visit and $1-2 \mathrm{~h}$ before the treatment. In this case, the patient should not drive a motor vehicle. ${ }^{5}$

\section{Local anesthesia in post-myocardial infarction patients}

Another important aspect of dental treatment is local anesthesia. If the patient's condition is stable and the medication is taken as prescribed, there are no contraindications for local anesthesia with adrenaline. Patients with ischemic heart disease are more vulnerable to the negative effects of the release of endogenous adrenaline as a result of severe pain during surgery than they are to a small amount of adrenaline in an anesthetic. ${ }^{22}$ A visit to the dental office is a stressful event, meaning the level of endogenous catecholamines increases more than after the administration of anesthesia. ${ }^{23}$ The level of endogenous adrenaline is naturally the highest between 8 and 11 a.m., so the visits should not be in the morning. ${ }^{9}$ Vanderheyden et al. showed that the highest increase in the level of adrenaline is associated with the beginning of the visit and the treatment itself. ${ }^{24}$ However, 
during the administration of anesthesia and immediately after the injection, increases in adrenaline levels were not observed. ${ }^{24}$ This means that most of the adrenaline is of endogenous origin, hence the reduction of stress and good, effective anesthesia are indicated. Moreover, local anesthetics without vasoconstrictors do not provide satisfactory hemostasis or anesthesia during dental procedures. ${ }^{25}$ However, it is recommended not to exceed $0.04 \mathrm{mg}$ of adrenaline, which corresponds to $21.8-\mathrm{cc}$ cartridges of an anesthetic with adrenaline at a dilution of $1: 100,000 .{ }^{14}$ If it is necessary to administer more anesthesia, subsequent portions should be administered without a vasoconstrictor. Intravascular anesthesia should be avoided. ${ }^{4}$ The use of intrapulpal and intraosseous anesthesia is contraindicated, as this could lead to the excessive absorption of adrenaline. ${ }^{9}$ For this reason, retraction cords impregnated with adrenaline should be avoided. However, in the case of untreated, unregulated arythmias or unstable angina, vasoconstrictor substances are contraindicated. Similarly, caution with the use of vasoconstrictors is indicated in patients with pacemakers, especially implantable automatic defibrillators. ${ }^{23}$ Elad et al. showed that local anesthesia using $4 \%$ articaine hydrochloride with adrenalin 1:200,000 is as safe as local anesthesia with $2 \%$ lidocaine and adrenalin 1:100,000 in cardiovascular patients. ${ }^{26}$ They observed neither severe adverse effects nor cardiac ischemic changes on electrocardiography (ECG) in either group. ${ }^{26}$

\section{Hemostasis in post-myocardial infarction patients}

Today the risk of complications of dental procedures is dependent more on the anticoagulant therapy used than on the severity of coronary heart disease. Patients who have had acute myocardial infarction always take medications that affect hemostasis. ${ }^{27}$ Depending on the indications, these are either antiplatelet drugs, vitamin $\mathrm{K}$ antagonists or new non-vitamin $\mathrm{K}$ antagonist oral anticoagulants (NOACs). The discontinuation of therapy with these drugs is associated with a high risk of complications, including death. This risk far exceeds the risk of increased bleeding during and after surgery. In addition, a surgical intervention itself increases the risk of deep vein thrombosis. Double antiplatelet therapy (DAPT) is aimed at preventing thrombosis in the coronary artery. The risk of thrombosis lasts until the atherosclerotic plaque stabilizes (a process taking about 4-6 weeks) or - in the case of stent implantation - until it is covered with the vascular endothelium (the conventional limit for metal stents is 1 month, and for coated stents 6-12 months). Double antiplatelet therapy includes acetylsalicylic acid (ASA) and an inhibitor of the P2Y12 glycoprotein receptor (clopidogrel, prasugrel or ticagrelor) (Table2). ${ }^{28}$ In cases when there is also a risk of cardiac embolism (atrial fibrillation, intracardiac thrombus) or concomitant venous thromboembolism, DAPT treatment is supplemented with an oral anticoagulant. ${ }^{28}$

Table 2. Recommendations for patients receiving drugs that affect hemostasis depending on the risk of excessive bleeding after dental procedures ${ }^{28}$

\begin{tabular}{|c|c|c|c|}
\hline Risk of bleeding in dental procedures & $\begin{array}{l}\text { Patients on ASA } \\
\text { and/or clopidogrel }\end{array}$ & $\begin{array}{l}\text { Patients on oral } \\
\text { anticoagulants }\end{array}$ & Patients on NOACs \\
\hline $\begin{array}{l}\text { Low risk of excessive bleeding: } \\
\text { 1. conservative and endodontic treatment; } \\
\text { 2. supragingival scaling; } \\
\text { 3. periodontal pocket probing; } \\
\text { 4. air polishing; } \\
\text { 5. extraction of } 1 \text { tooth or teeth that are loose; } \\
\text { 6. single implant placement; } \\
\text { 7. laser evaporation of oral mucosa lesions. }\end{array}$ & $\begin{array}{c}\text { continue therapy } \\
\text { without } \\
\text { any changes }\end{array}$ & check if INR $<3$ & $\begin{array}{c}\text { continue therapy } \\
\text { without } \\
\text { any changes }\end{array}$ \\
\hline $\begin{array}{l}\text { Moderate risk of excessive bleeding: } \\
\text { 1. subgingival scaling; } \\
\text { 2. root debridement; } \\
\text { 3. frenulectomy; } \\
\text { 4. periodontal flap surgery; } \\
\text { 5. guided tissue regeneration; } \\
\text { 6. tooth extraction with flap elevation; } \\
\text { 7. extraction of impacted teeth; } \\
\text { 8. root resection; } \\
\text { 9. vestibuloplasty; } \\
\text { 10. several implant placement; } \\
\text { 11. closed sinus lift procedure; } \\
\text { 12. excisional or incisional biopsy. }\end{array}$ & $\begin{array}{c}\text { continue therapy } \\
\text { without } \\
\text { any changes }\end{array}$ & check if INR $<3$ & $\begin{array}{l}\text { stop therapy with rivaroxaban } \\
-24 \mathrm{~h} \text { before surgery, } \\
\text { and with dabigartan }-1-2 \text { days } \\
\text { before surgery } \\
\text { restart therapy } 24-48 \mathrm{~h} \text { after } \\
\text { surgery }\end{array}$ \\
\hline $\begin{array}{l}\text { High risk of excessive bleeding: } \\
\text { 1. soft tissue augmentation with free gingival grafts } \\
\text { or connective tissue grafts; } \\
\text { 2. placement of 6-8 implants in the edentulous } \\
\text { alveolar ridge; } \\
\text { 3. bilateral open sinus lift procedure; } \\
\text { 4. oncological, orthognathic and reconstructive surgery. }\end{array}$ & $\begin{array}{l}\text { continue therapy with ASA } \\
\text { stop therapy with P2Y12 inhibitors } \\
\text { 24-72 h before surgery } \\
\text { in patients at high risk of thrombosis, } \\
\text { consider glycoprotein Ila/Illa inhibitors }\end{array}$ & $\begin{array}{l}\text { check if INR = 2-2.5 } \\
\text { convert to heparin } \\
\text { only in selected cases }\end{array}$ & $\begin{array}{l}\text { stop therapy with rivaroxaban } \\
-24 \mathrm{~h} \text { before surgery, } \\
\text { and with dabigartan } \\
-1-2 \text { days before surgery } \\
\text { restart therapy } 24-48 \mathrm{~h} \\
\text { after surgery }\end{array}$ \\
\hline
\end{tabular}


Coronary angiography is routinely performed in patients with acute coronary syndrome, and if the coronary artery responsible for myocardial infarction is identified, a revascularization procedure is performed. Coronary angioplasty is the most common one, with the implantation of an anti-proliferative eluting stent, coated with a cytostatic agent that inhibits cell division. This limits the inflammatory process and the formation of restenosis in the vessel, but at the same time slows down the epithelialization of the stent and prolongs the need for DAPT. New drug-eluting stents require the use of 2 antiplatelet drugs for about 6 months, or 12 months if they are implanted due to acute coronary syndrome. This is a conventional time period to allow the vascular endothelium to grow. The earlier discontinuation of therapy may result in acute thrombosis in the stent, myocardial infarction and death. In exceptional situations, metal stents are used; their epithelialization takes 1 month. ${ }^{28}$

The time limits for DAPT were modified by the ESC guidelines published in $2017 .{ }^{28}$ Two scales were created to establish a safe date for ending the treatment. The PRECISE-DAPT score is used for stent implantation based on the results of laboratory tests (hemoglobin, leukocytes, creatinine clearance) and the patient's data (age, history of bleeding), and indicates either a brief (3-6 months) or extended (12-24 months) use of DAPT. Longer therapy may be beneficial and may lower the risk of stent closing. However, the duration of therapy depends on individual factors (e.g., age, comorbidities, left ventricular ejection fraction (LVEF), bleeding risk, or smoking) as well as on the procedure technique (implanted stent caliber, type of substance released, presence of a stent in the vein bridge). ${ }^{28,29}$

In 2016, Pruszczyk et al. published (in Polish) a paper detailing a protocol for preparing patients on anticoagulants for dental surgical procedures. ${ }^{30}$ It follows the guidelines set out by ESC and the European Association for CardioThoracic Surgery (EACTS). ${ }^{28}$ Most dental procedures are defined as low-risk in terms of blood loss, and hemostasis can be achieved through the use of local hemostatic agents. There is a greater risk of blood loss associated with major reconstructive procedures, bone block transplants, implantological procedures, extractions of more than 3 teeth, treatment with the elevation of the mucoperiosteal flap, soft tissue augmentation procedures, connective tissue grafts, and open sinus lift procedures. The 4 criteria for abundant post-operative bleeding are: bleeding lasting longer than $12 \mathrm{~h}$, forcing the patient to report to the dental office or the emergency room, hematoma or bruising, and need for a blood transfusion. ${ }^{30}$

The effect of antiplatelet therapy may double the bleeding time, but in most cases, it remains within the normal range or only slightly over it. ${ }^{30}$ The results of the platelet aggregation test might be abnormal, although without clinical consequences. ${ }^{31}$ Prolonged bleeding time is not a major clinical problem, since hemostasis can be achieved by pressure, suturing, applying collagen sponges, or prescribing tranexamic acid. As mentioned above, the discontinuation of antiplatelet therapy is the main cause of late stent thrombosis, which can result in serious complications, including death (in up to $45 \%$ of cases) and significant damage to the heart. ${ }^{32}$ The safety of surgical dental procedures during antiplatelet therapy was confirmed by Park et al. ${ }^{33}$ Among 100 patients undergoing combined antiplatelet therapy with ASA, clopidogrel and, in some cases, with the addition of cilostazol, only 2 patients had increased post-operative bleeding after tooth extraction and in both, it was enough to apply pressure to stop the bleeding. ${ }^{31}$ Dodson demonstrated that the amount of bleeding measured during invasive procedures was similar in the group of patients who suspended their ASA therapy for 7 days before tooth extraction and in patients who continued their ASA therapy. ${ }^{32}$ However, Buhatem Medeiros et al. showed that patients on DAPT presented a larger volume of bleeding during invasive procedures than patients not using these medications. ${ }^{34}$ Local hemostatic methods were sufficient to control the bleeding and there were no post-operative bleeding complications in any of the presented cases. ${ }^{34}$ When in doubt, it is recommended to check prothrombin time (PT), partial thromboplastin time (PTT) and the number of platelets. If PT and PTT are found to be within the normal range and the number of platelets exceeds $100,000 / \mathrm{mm}^{3}$, surgery can safely be performed. ${ }^{31}$ In more complicated surgical procedures with a moderate bleeding risk, patients should be maintained on aspirin, while P2Y12 inhibitor therapy should be discontinued. ${ }^{30}$

Vitamin $\mathrm{K}$ antagonists warfarin and acenocoumarol are used in conditions associated with coronary heart disease, including the prophylaxis of venous thromboembolism, and in patients with arythmias, artificial valves, thrombophilia, and antiphospholipid syndrome. ${ }^{35,36}$ In these cases, the administration of vitamin $\mathrm{K}$ antagonists should not be stopped before any dental procedures - including procedures of a higher risk of bleeding - if the patient's international normalized ratio (INR) $<324 \mathrm{~h}$ before the planned procedure. ${ }^{34}$ If the patient's INR $>3$, the attending physician should adjust the therapy to achieve a lower INR. ${ }^{30}$ The withdrawal of oral anticoagulants does not guarantee that bleeding will not occur; serious bleeding occurs also in patients who have never taken anticoagulants. Only $0-3.5 \%$ of cases of excessive bleeding are so severe that they cannot be controlled with local measures. A higher risk of death or permanent disability is associated with the discontinuation of anticoagulant treatment. In a relapse of venous thromboembolism, the risk of death is $6 \%$ and of permanent disability $2 \%$. In the case of arterial embolism, the former risk is $20 \%$ and the latter $40 \%{ }^{37}$ It should be emphasized that there is no description in the literature of any case of death or permanent disability resulting from massive bleeding after a dental procedure in a patient taking anticoagulants. It should be borne in 
mind that during anticoagulant therapy, the administration of tetracyclines, erythromycin, clarithromycin, and metronidazole is contraindicated. ${ }^{9}$

Newer anticoagulants are direct inhibitors of factor Xa - rivaroxaban, apixaban and edoxaban, and direct thrombin inhibitor dabigatran. They are used in deep vein thrombosis, pulmonary embolism, embolism due to non-valvular atrial fibrillation, following orthopedic surgery as well as in acute coronary syndrome and venous thromboembolism. There are no unambiguous guidelines of how to proceed with the use of these drugs in planned surgical procedures. The manufacturers of these drugs recommend a break of 1 day in pharmacotherapy, extended to 2 days in cases of impaired renal function with glomerular filtration rate (GFR) lowering to $30 \mathrm{~mL} / \mathrm{min} / 1.73 \mathrm{~m}^{2}$. It is recommended that the procedure should be performed when the drug concentration is the lowest, i.e., $12 \mathrm{~h}$ or $24 \mathrm{~h}$ after the last dose, depending on whether the drugs are taken once or twice daily. If procedures of a high risk of bleeding are planned and the medications are taken in the morning, the dose of the drug used once a day (edoxaban) should be delayed until after the procedure, whereas in the case of the drugs taken twice daily (apixaban, dabigatran and rivaroxaban), the evening dose should be skipped. If edoxaban is taken in the evening, there is no need to skip the dose. If complete hemostasis is obtained during the procedure, the dose that was previously skipped can be taken after $6-8$ h. ${ }^{37}$ In patients taking medications affecting hemostasis, it is recommended that dental procedures should be performed early enough during the day to allow the patient to seek help in case of prolonged bleeding. Likewise, treatment should be carried out at the beginning of the week, as re-bleeding usually takes place after $24-48 \mathrm{~h} .{ }^{38}$ The use of an infiltration anesthetic with a vasoconstrictor is recommended and nerve block anesthesia should be avoided if possible. If nerve block anesthesia is necessary, it should always be performed with aspiration.

Following an extraction, the tooth socket should be provided with a hemostatic dressing and sutured well for 7-14 days, and gauze pad compression should be maintained for 30 min after treatment. ${ }^{36}$ The patient should be advised not to rinse their mouth for $24 \mathrm{~h}$, not to perform suction or create negative pressure in the mouth, not to touch the alveolus with the tongue or any foreign body, to avoid hot and hard food, and not to bite on the side of the procedure. The patient should be advised to apply pressure for $20 \mathrm{~min}$ with a clean gauze pad in case of bleeding, and contact the dentist if hemostasis does not occur. ${ }^{30,38}$

\section{Conclusions}

Patients who have suffered a heart attack often require dental treatment. The inflammation of the oral cavity not only reduces the quality of life, but can also contribute to the deterioration of the course of ischemic heart disease. In most cases, dental treatment can be under- taken 6 weeks after myocardial infarction. It is important to eliminate pain, so local anesthesia with a vasodilator in a dose not exceeding $0.04 \mathrm{mg}$ should be used. Antibiotic prophylaxis is usually not required. Visits should be short and carried out in the early afternoon. The patient should be in a comfortable sitting position. If the patient complains of retrosternal pain, the procedure should be discontinued, and oxygen and nitrates should be administered. If there is no improvement, a re-infarction should be suspected and an ambulance should be called immediately. In the vast majority of cases, antiplatelet drugs and anticoagulants should not be discontinued prior to planned surgery, since there is a significantly higher risk of thromboembolism than of increased bleeding in these patients. In case of any doubts as to the patient's health and the possibility of dental treatment, the patient should be referred to a specialist to establish an individualized treatment plan.

\section{ORCID iDs}

Renata Samulak-Zielińska (D) https://orcid.org/0000-0003-0145-9131 Elżbieta Dembowska (D) https://orcid.org/0000-0002-3646-1314 Piotr Lizakowski (1) https://orcid.org/0000-0001-5648-2027

\section{References}

1. Bhateja S. High prevalence of cardiovascular diseases among other medically compromised conditions in dental patients: A retrospective study. J Cardiovasc Dis Res. 2012;3(2):113-116.

2. Włosowicz M, Wozakowska-Kapłon B, Górska R. Periodontitis in relation to selected parameters of cardiovascular system in the group of patients with acute myocardial infarction [in Polish]. Czas Stomatol. 2012;65(5):636-653.

3. Chaudhry S, Jaiswal R, Sachdeva S. Dental considerations in cardiovascular patients: A practical perspective. Indian Heart J. 2016;68(4):572-575.

4. Kebschull M, Demmer RT, Papapanou PN. "Gum bug, leave my heart alone!" - epidemiologic and mechanistic evidence linking periodontal infections and atherosclerosis. J Dent Res. 2010;89(9):879-902.

5. Cruz-Pamplona $M$, Jimenez-Soriano $Y$, Sarrión-Pérez MG. Dental considerations in patients with heart disease. J Clin Exp Dent. 2011;3(2):e97-e105.

6. Górski B, Włosowicz M, Dembowska E, Kręgielczak A, Górska R. More than $40 \%$ patients after cardiac infarct require immediate application of specialist periodontal treatment [in Polish]. Magazyn Stomatol. 2014;24(1):95-98.

7. Napeñas JJ, Kujan O, Arduino PG, et al. World Workshop on Oral Medicine VI: Controversies regarding dental management of medically complex patients: Assessment of current recommendations. Oral Surg Oral Med Oral Pathol Oral Radiol. 2015;120(2):207-226.

8. Pedersen F, Butrymovich V, Kelbæk H, et al. Short- and long-term cause of death in patients treated with primary PCI for STEMI. J Am Coll Cordial. 2014;64(20):2101-2108.

9. Thygesen K, Alpert JS, Jaffe AS, Simoons ML, Chaitman BR, White HD. Third universal definition of myocardial infarction. Circulation. 2012;126(16):2020-2035.

10. Research, Science and Therapy Committee, American Academy of Periodontology. Periodontal management of patients with cardiovascular diseases. J Periodontol. 2002;73(8):954-968.

11. Niwa $H$, Sato $Y$, Matsuura $H$. Safety of dental treatment in patients with previously diagnosed acute myocardial infarction or unstable angina pectoris. Oral Surg Oral Med Oral Pathol Oral Radiol Endod. 2000;89(1):35-41.

12. Roberts HW, Mitnitsky EF. Cardiac risk stratification for postmyocardial infarction dental patients. Oral Surg Oral Med Oral Pathol Oral Radiol Endod. 2001;91(6):676-681. 
13. Silvestre FJ, Miralles-Jorda L, Tamarit C, Gascon R. Dental management of the patient with ischemic heart disease: An update. Med Oral. 2002;7(3):222-230.

14. Napora M. Antibiotics prophylaxis for patients at high risk of infectious endocarditis [in Polish]. Nowa Stomatol. 2008;13(1):24-26.

15. Habib G, Lancellotti P, Antunes MJ, et al. ESC guidelines for the treatment of infective endocarditis in 2015 [in Polish]. Kardiol Pol. 2015;73(11):963-1027.

16. Kaczmarzyk T, Babiuch K, Bołtacz-Rzepkowska E, et al. Rekomendacje Grupy Roboczej Polskiego Towarzystwa Stomatologicznego i Narodowego Programu Ochrony Antybiotyków w zakresie stosowania antybiotyków w stomatologii. Warsaw, Poland: Narodowy Instytut Leków; 2019.

17. Roberts HW, Redding SW. Coronary artery stents: Review and patientmanagement recommendations. J Am Dent Assoc. 2000;131(6):797-801.

18. AAE Quick Reference Guide: Antibiotic Prophylaxis 2017 Update. https://www.aae.org/specialty/wp-content/uploads/sites/2/2017/06/ aae_antibiotic-prophylaxis-2017update.pdf

19. Kaura A, Dworakowska D, Dworakowski R. Infective endocarditis - Cinderella in cardiology. Kardiol Pol. 2017;75(10):965-974.

20. Wilson W, Taubert KA, Gewitz M, et al.; American Heart Association Rheumatic Fever, Endocarditis, and Kawasaki Disease Committee; American Heart Association Council on Cardiovascular Disease in the Young; American Heart Association Council on Clinical Cardiology; American Heart Association Council on Cardiovascular Surgery and Anesthesia; Quality of Care and Outcomes Research Interdisciplinary Working Group. Prevention of infective endocarditis: Guidelines from the American Heart Association: A guideline from the American Heart Association Rheumatic Fever, Endocarditis, and Kawasaki Disease Committee, Council on Cardiovascular Disease in the Young, and the Council on Clinical Cardiology, Council on Cardiovascular Surgery and Anesthesia, and the Quality of Care and Outcomes Research Interdisciplinary Working Group. Circulation. 2007;116(15):1736-1754.

21. Rose LF, Mealey B, Minsk L, Cohen DW. Oral care for patients with cardiovascular disease and stroke. J Am Dent Assoc. 2002;133(Suppl):37S-44S.

22. Laragnoit AB, Neves RS, Neves ILI, Vieira JE. Locoregional anesthesia for dental treatment in cardiac patients: A comparative study of $2 \%$ plain lidocaine and $2 \%$ lidocaine with epinephrine (1:100,000). Clinics (Sao Paulo). 2009;64(3):177-182.

23. Margaix Muñoz M, Jiménez Soriano Y, Poveda Roda R, Sarrión G. Cardiovascular diseases in dental practice. Practical considerations. Med Oral Pathol Oral Cir Bucal. 2008;13(5):E296-E302.

24. Vanderheyden PJ, Williams RA, Sims TN. Assessment of ST segment depression in patients with cardiac disease after local anesthesia. J Am Dent Assoc. 1989;119(3):407-412.

25. Daskalov H, Dinkova A, Drangov M. Local anesthetics in patients with cardiovascular diseases. J of IMAB. 2015;21(1):728-731.

26. Elad S, Admon D, Kedmi M, et al. The cardiovascular effect of local anesthesia with articaine plus 1:200,000 adrenalin versus lidocaine plus 1:100,000 adrenalin in medically compromised cardiac patients: A prospective, randomized, double-blinded study. Oral Surg Oral Med Oral Pathol Oral Radiol Endod. 2008;105(6):725-730.

27. Skaar D, O'Connor H, Lunos S, Luepker R, Michalowicz BS. Dental procedures and risk of experiencing a second vascular event in a Medicare population. J Am Dent Assoc. 2012;143(11):1190-1198.

28. Valgimigli $M$, Bueno $H$, Byrne RA, et al.; ESC Scientific Document Group; ESC Committee for Practice Guidelines (CPG); ESC National Cardiac Societies. 2017 ESC focused update on dual antiplatelet therapy in coronary artery disease developed in collaboration with EACTS: The Task Force for dual antiplatelet therapy in coronary artery disease of the European Society of Cardiology (ESC) and of the European Association for Cardio-Thoracic Surgery (EACTS). Eur Heart J. 2018;39(3):213-260.

29. Levine GN, Bates ER, Bittl JA, et al. 2016 ACC/AHA guideline focused update on duration of dual antiplatelet therapy in patients with coronary artery disease: A report of the American College of Cardiology/American Heart Association Task Force on Clinical Practice Guidelines. J Thorac Cardiovasc Surg. 2016;152(5):1243-1275.

30. Pruszczyk P, Ciurzyński M, Opolski G, et al. Dental cardio common position for dealing anticoagulation in patients undergoing dental procedures [in Polish]. Kardiol Pol. 2016;74(1):87-98.
31. Gziut Al. Late in-stent thrombosis as a cause of acute coronary syndrome complicated by out-of-hospital cardiac arrrest [in Polish]. Kardiol Pol. 2008;66(6):697-699.

32. Dodson T. Should acetylsalicylic acid (ASA) therapy for prevention of thromboembolic events be stopped prior to surgical extractions? Evid Based Dent. 2012;13(3):89-90.

33. Park MW, Her SH, Kwon JB, et al. Safety of dental extractions in coronary drug-eluting stenting patients without stopping multiple antiplatelet agents. Clin Cardiol. 2012;35(4):225-230.

34. Buhatem Medeiros F, Pepe Medeiros de Rezende N, Bertoldi Franco J, et al. Quantification of bleeding during dental extraction in patients on dual antiplatelet therapy. Int J Oral Maxillofac Surg. 2017;46(9):1151-1157.

35. Singh S, Gupta K, Garg KN, Fuloria NK, Fuloria S, Jain T. Dental management of the cardiovascular compromised patient: A clinical approach. J Young Pharm. 2017;9(4):453-456.

36. Milczarek S, Smektała T, Jędrzejewski M, Szyndel J, Sporniak-Tutak K. Dental procedures in patients with coexistent blood clotting disorder or arterial hypertension. Pt 2. Procedure with patients taking oral anticoagulants or modern anticoagulants [in Polish]. Magazyn Stomatol. 2013;23(12):116-118.

37. Pototski M, Amenábar JM. Dental management of patients receiving anticoagulation or antiplatelet treatment. J Oral Sci. 2007:49(4):253-258.

38. Dézsi CA, Dézsi BB, Dézsi AD. Management of dental patients receiving antiplatelet therapy or chronic oral anticoagulation: A review of the latest evidence. Eur J Gen Pract. 2017;23(1):196-201. 